\title{
Points of View
}

\section{Delineation of the Pannonian vegetation region}

\author{
G. Fekete ${ }^{1}$, G. Király² and Zs. Molnár ${ }^{3}$ \\ ${ }^{1}$ Dávid F. u. 9, H-1113 Budapest, Hungary \\ 2Institute of Silviculture and Forest Protection, University of West Hungary, Ady E. u. 5, H-9400 Sopron, Hungary \\ ${ }_{3}^{3}$ MTA Centre for Ecological Research, Institute of Ecology and Botany, Alkotmány u. 2-4, H-2163 Vácrátót, Hungary. \\ Corresponding author.Email: molnar.zsolt@okologia.mta.hu
}

Keywords: Flora, Pannonian vegetation types, Potential natural vegetation, Quercetum petraeae-cerridis, Vegetation geography, Vegetation map, Zonality.

\begin{abstract}
Phytogeographical regions have been set up traditionally on the basis of the flora. Several examples indicate that the potential natural vegetation is also suitable for this purpose although the flora- and vegetation-based boundaries do not necessarily overlap. We define a vegetation region as an area where the physical geographic features are rather uniform, and which consists of landscapes with floristically/structurally similar vegetation and/or their repetitive mosaics. In this paper, we delimited the boundaries of the Pannonian region based on the distribution of characteristic plant communities. The line runs most often on the border between Quercus cerris-Quercus petraea and Carpinus betulus/Fagus sylvatica dominated landscapes. We provided descriptions of the potential vegetation on both sides of the boundary. The region has an area of $167,012 \mathrm{~km}^{2}$. The region is either in direct contact with the neighboring regions (e.g., Western Carpathians), or is separated from them by transitional areas (towards the Eastern Alps), and character-poor areas with non-Pannonian, non-Alpine, non-Dinaric vegetation (in the southwest to the Western Balkan). Often, the boundary does not coincide with the boundary of the Pannonicum floristic province. We found that vegetation region boundaries can help reevaluate long-established floristic region boundaries. The boundary of the 'floristic Pannonian region' also requires revision based on integrated distribution databases and statistical analyses. We argue that the method applied here is simple, repeatable and falsifiable. Our map provides an opportunity to the European Union to use a scientifically more sound biogeographical circumscription of the Pannonian region in her Natura 2000 and other programs.
\end{abstract}

\section{Introduction}

Phytogeographical regions have been set up traditionally on the basis of the flora of the studied area (Walter and Straka 1970, González-Orozco et al. 2014). Thus, the boundaries are the function of the geographic distribution of a large number of species - which rarely coincide. One has to select a subset of species to be used, but the choice is not entirely without subjective decisions. It would be therefore useful to use a simpler and more objective method for biogeographic regionalization. Several example indicate that vegetation is suitable for this purpose (Schmithüsen 1968, Schubert 1991, Hegg et al. 1993, Bailey 2005, Zhang 2007, Molnár et al. 2008a etc.). Dierschke (1994) discussed delimitations based on vegetation and terms such as vegetation sector, vegetation province, vegetation region, etc. (see also Schmithüsen 1968). Larger spatial units of ,vegetation areas" (Vegetationsgebiete) may be composed of spatially neighboring smaller units that have their own characeristic plant communities and their complexes, furthermore specific floristic and physiognomic features, e.g., endemic taxa, related formations (Dierschke 1994). A biogeographical region defined by its vegetation (hereinaf- ter vegetation region) is an area above the landscape scale, where the physical geographic features are rather uniform and which consists of landscapes with floristically and structurally similar vegetation and/or repetitive mosaics of such landscapes (Fekete et al. 2014).

The delimitation of vegetation regions has often been based on maps of the potential natural vegetation (e.g., Küchler 1985). Bailey (2005) used vegetation beside climate when drawing the ecoregion map of the United States. The biogeographical regionalization of China is also based on vegetation (Zhang 2007). The biogeographical division of Europe has been completed on the basis of plant communities and vegetation complexes (Schubert 1991). Vegetation-based geographical division of countries into smaller units is available in Switzerland (Hegg et al. 1993) and Hungary (Molnár et al. 2008a).

The Pannonian floristic province (Pannonicum) is a widely accepted biogeographical region in Central Europe, a separate unit in phytogeographical maps prepared at different scales (e.g., maps of Eurasia: Meusel et al. 1965, Meusel and Jäger 1992, maps of Europe: Soó 1932, 1965). 
It covers the inner parts of the Carpathian basin reaching out from the Basin only in north-west. The Carpathian Basin is characterized by a great wealth of floristic elements from different parts of Eurasia. In addition to the broadly distributed Eurasian species, the proportion of sub-Mediterranean, continental, Pontic and Balkanian species is also substantial. Its floristic distinctiveness comes from the combination of these floristic elements, as well as the occurrence of Pannonian endemics. Delimitation of the Pannonicum was attempted first by Kerner and Wettstein (1888), Borbás (1905) and Rapaics (1910). Jávorka (1924-1925) and Soó (1933, 1945, 1947) prepared the first detailed cartographic delimitation of the region (Fig. 1).

It seems likely that the sections of the boundary of the Pannonicum floristic province running across eight countries were not delimited by the same precision. Thus, the floristic boundary should be revised in the future using standard methodology and a fixed scale. New enumerations of local floras and the new modern flora databases could effectively help this work. However, determination of the boundaries of the Pannonicum floristic province with sufficient precision is likely to be a long and laborious process. We argue that using vegetation as a basis for the delineation of the Pannonian region would be quicker and more homogenous in content. We accept, however, that the flora and vegetation-based boundaries of the region do not necessarily overlap.

The vegetation of the Pannonicum has been characterized recently by Fekete et al. (2014) based on three newly developed concepts: distributional regularity (e.g., the altitudinal pattern of vegetation belts, and the gradient of continentality along the mountain ranges), distributional deviation (the conspicuous departure of vegetational phenomena from the expected pattern expressed as regularity), and compositional uniqueness (e.g., the endemic zonal forest-steppe forests and intrazonal endemic communities). Following these concepts, we describe the boundaries of the Pannonian vegetation region. We use the term vegetation region in a broad sense not specifying it in a hierarchical order (Dierschke 1994).

The vegetation-geographical delimitation of the Pannonian region proved to be timely and possible for several reasons. On the one hand, almost all affected countries have completed their own maps of the potential vegetation (Hungary: Zólyomi 1989, Slovakia: Michalko et al. 19841986, Yugoslavia: Jovanović et al. 1986, Romania: Ivan et al. 1993; a countrywide mapping of current habitats has also been completed in Hungary, see Bölöni et al. 2008, Molnár et al. 2008b), and simultaneously, large amounts of geobotanical information have been accumulated in these countries. On the other hand, the European conservation authorities in their Habitat Directive drew an imprecise and thus misleading boundary of the Pannonian biogeographical region, particularly in the west and the south, where the boundary runs along the border of the European Union of the time (Anon. 2014, Fig. 1). This also has motivated us to develop a more scientifically sound method and come up with a more accurate boundary line.

\section{Materials and methods}

\section{Data sources of delineation}

In drawing the boundary of the Pannonian vegetation region, we used maps of the potential vegetation and local vegetation descriptions, in addition to our own field experience:

1) map of the potential natural vegetation of Hungary (1: 1,500,000, Zólyomi 1967, 1989) and works on the vegetation of the border zone (e.g., Zólyomi 1941, Jeanplong 1956 , Pócs 1960);

2) map of the natural potential vegetation of Czechoslovakia (1: 200,000, for Slovakia: Michalko et al. 1984-1986, and for the Czech Republic: Mikyška et al. 1968-1972) and the attached explanatory text (Michalko et al. 1987), and an earlier 1: 500,000 scale map for Slovakia (Michalko et al. 1979);

3) map and description of the natural potential vegetation of Yugoslavia (Fukarek and Jovanović 1986);

4) map of the potential vegetation of Romania (Ivan et al. 1993);

5) map of the natural vegetation of the countries along the Danube river (1: 2,000,000, Niklfeld 1974);

6) map of the potential vegetation of Europe (1:25,000,000, Bohn et al. 2000);

7) distribution maps of current habitats derived from the Hungarian habitat mapping database (Molnár et al. 2007, Molnár et al. 2008b, Bölöni et al. 2008), habitat descriptions (Bölöni et al. 2011), and descriptions of geographical microregions of Hungary based on the flora and vegetation (Király et al. 2008), and finally

8) vegetation descriptions, phytosociological tables from the margins of the region (see references mentioned above).

\section{Pannonian plant communities of the study area}

To determine the boundaries of the Pannonian vegetation region, we used plant communities that are regarded typical for the interior of the Carpathian Basin, and thus are considered Pannonian (Fekete et al. 2014).

They include the still widespread and climatically zonal or edaphic communities and also intrazonal communities, which occur within the belt of these vegetation types. The Pannonian character of the communities was assessed with the help of the rich phytosociological literature. In the descriptions below, the names of plant communities follow Borhidi et al. (2012). For more detailed descriptions, see Borhidi et al. (2012) and the publications listed in the references. Nomenclature of flowering plants follows Király (2009). Geographical names used in the text are given in the local official language or in English. The most extensive Pannonian communities are as follows:

Oak steppe forest on loess with Acer tataricum: the climatically zonal forest community on the lower foothills of the mountain ranges bordering the Great Hungarian Plain and on the loess-covered parts of the latter is Quercetum pubescenti- 
roboris. This community is a representative of the sub-Mediterranean variant of the forest steppe vegetation. The co-occurrence of Quercus robur and Quercus pubescens as forest dominants (unlike in Eastern Europe) and the frequency of their hybrids are a Pannonian feature. Acer tataricum may often form a lower forest canopy layer. The herb layer includes several forest-steppe species of tall forbs. The grassland component of the forest steppe is represented by species-rich meadow steppe (i.e., Salvio nemorosae-Festucetum rupicolae, Euphorbio pannonicae-Brachypodietum pinnati).

Oak steppe forests on sand: these xeric and xeromesic oak forests are restricted to extensive sandy regions and are unique to the Carpathian Basin. The rather closed types Convallario- and Polygonato latifolii-Quercetum roboris and the somewhat open Festuco rupicolae- and Iridi variegatae-Quercetum roboris communities require the presence of groundwater within reach of roots. The most open type of woody vegetation is Junipero-Populetum albae on the driest sand dunes.

Open sand steppe: formed by Festucetum vaginatae community with Stipa borysthenica and Festuca wagneri at places. The number of Pannonian endemics (mainly on the sand between the Danube and Tisza rivers) is the highest in this community. Many of its common species have Pontic, Ponticsub-Mediterranean and continental range of distribution.

Oak steppe forests on solonetz soil: The typical open forest of the forest steppe with a mosaic-like structure (community Galatello-Quercetum roboris) is almost unknown in other parts of Europe. The vegetation in the glades (PeucedanoAsteretum sedifolii) is the westernmost representative of an intrazonal vegetation type distributed from South Siberia as far west as East Central Europe.

Halophytic herbaceous vegetation: Halophytic grasslands and marshes are widespread in the Pannonian region (e.g., Artemisio santonici-Festucetum pseudovinae, Agrostio stoloniferae-Alopecuretum pratensis, Lepidio crassifoliaeCamphorosmetum annuae, and Puccinellietum limosae). The Pannonian halophytic vegetation greatly differs from the saline maritime communities of European coastal areas in both soil development and dynamics, as well as in the origin of species. The distinction is further amplified by the occurrence of some endemics. The majority of the characteristic species have Pontic-Pannonian and even Irano-Turanian range of distribution.

Hardwood riparian forests: The potential vegetation types on the high-lying parts of the floodplains along lowland rivers are Fraxino pannonicae-Ulmetum and its allies. The Pannonian character is due mostly to the occurrence of Fraxinus angustifolia subsp. pannonica and Acer tataricum.

Forests of Quercus petraea-Quercus cerris: The most widespread zonal forest community on the low hills and lower mountain regions in the Pannonian region is Quercetum petraeae-cerridis. One of the dominant species, Quercus cerris, has an eastern sub-Mediterranean area of distribution, and is an indicator of climate. The northern boundary of its distribution range (Fekete and Blattny 1913) within the Carpathian Basin fits well the "Moesz-line", which is the northernmost limit for the distribution of Pannonian species and also grape cultivation (Moesz 1911). The constant species in the Quercetum petraeae-cerridis are mostly sub-Mediterranean, sub-Mediterranean-Central European, and PannonianBalkanian species. The co-dominant tree in the community is the Central European Quercus petraea. The co-dominance of the two oak species clearly attests the transitional character of the Pannonian region. In terms of floristic composition, the Quercetum petraeae-cerridis shows some intermediate features between the Sarmatian Potentillo albae-Quercetum roboris and the northeast Balkanian Quercetum farnetto-cerridis (Soó 1963). It is a distinct Pannonian community despite the absence of Pannonian endemisms, which differs from both communities above, although it is more closely related syntaxonomically to the latter one. These forests were once directly adjacent to the Quercetum pubescenti-roboris forests of the forest steppe, and they may share numerous Eurasian, south and southeast European, continental and PannonianBalkanian species that are characteristic of the FestucoBrometea class (Kovács 1975, Kovács and Podani 1979).

Despite the most recent phytosociological classification (Borhidi et al. 2012), we consider the related AsphodeloQuercetum roboris community (Borhidi and Járai-Komlódi 1959, Tallós 1959, Kevey 2008, 2011) Pannonian rather than Illyrian. In addition to the occasional occurrence of a few sub-Mediterranean, sub-Atlantic-sub-Mediterranean and Illyrian species, it shares several dozens of species with the zonal Pannonian Quercetum petraeae-cerridis forests. The Agrostio tenuis-Quercetum cerridis community (Csapody 1974 ) is similar, but without any Illyrian character (Kevey 2008, Király and Király 2008). Both communities bear some forest-steppe features as well (Zólyomi 1941, Borhidi and Járai-Komlódi 1959, Kevey 2011).

The Pannonian character of the Quercetum petraeae-cerridis belt is further accentuated by the presence of intrazonal edaphic and often endemic communities. The most widespread of them are Pannonian oak scrubs (Cotino-Quercetum pubescentis, Ceraso mahaleb-Quercetum pubescentis) growing primarily on dry and warm limestone and dolomite hillsides. They are characterized by an open, mosaic-like structure with glades, stunted growth of Quercus pubescens and Fraxinus ornus, and high species richness in the forest margin ecotones. The main forest trees and many of the shrubs are species growing mainly in the Northern Balkan, whereas the herbaceous component is also rich in continental steppe elements. This dual character is a Pannonian feature (Fekete et al. 2014). The dolomitic rock grassland (Seseleo leucospermi-Festucetum pallentis) exclusively hosts several Pannonian endemics. Other less widespread Pannonian communities are Waldsteinio-Spiraeetum mediae, Tilio-Fraxinetum excelsioris, Poetum scabrae, and Campanulo macrostachyae-Stipetum tirsae.

\section{Method of delineation}

The boundary line of the Pannonian vegetation region was drawn onto the map of the natural vegetation of Europe 


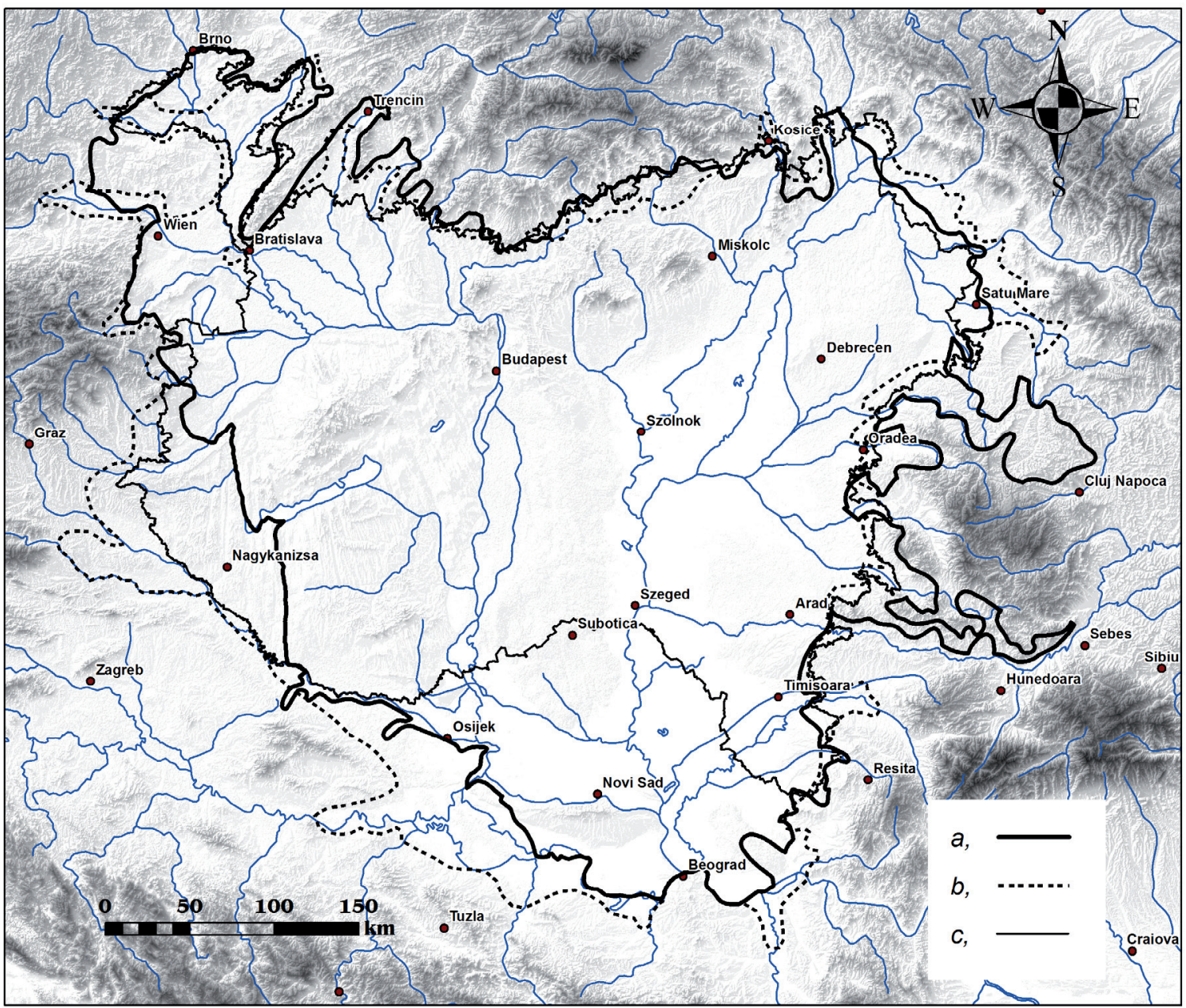

Figure 1. The boundary lines of the a) Pannonian vegetation region; b) the Pannonicum floristic region based on latest version covering the whole region (Soó 1947); and c) the Pannonian biogeographic region of the European Union (Natura 2000, Anon. 2014, note: it often runs on country borders) (source of base map: ASTER-GDEM, 2009, NASA).

(Bohn et al. 2000). On this map, all the important zonal Pannonian communities are identifiable.

First, we drew a preliminary line along the external border of the areas with Pannonian vegetation. This was followed by a detailed test. Information for this test came from finerscale maps, a large number of vegetation descriptions, and our own personal field observations at places. We checked the base map patch by patch whether patches were identified and their borders were drawn correctly, and whether merging certain patches on the map were justifiable. The final boundary line was established after completing all the necessary corrections.

We considered an area as part of the Pannonian vegetation region if Pannonian vegetation types covered more than $50 \%$ of it, or if azonal vegetation was predominant and nonPannonian vegetation types (like Fagetalia-communities) took up a negligible portion of the vegetation. In most cases, the boundary was drawn along the outer margin of the geographical range of a Pannonian community, usually between
Quercetum petraeae-cerridis communities and forests dominated by Carpinus betulus/Fagus sylvatica.

In cases when a Pannonian community or vegetation complex fully surrounded smaller areas mostly dominated by Carpinus betulus/Fagus sylvatica forests, the latter were included in the Pannonian vegetation region (these isolated occurrences of non-Pannonian vegetation were not indicated on our maps).

When an area between two vegetation regions was occupied by azonal riparian vegetation, we arbitrarily set the boundary along the current course of the river. If an adjoining area did not show characteristic features of a vegetation region, but was covered with vegetation other than riparian communities, we set the boundary on its adjoining edge. In case of some ambiguous sections, we consulted local and regional experts. For every boundary section, we provided the names of the typical vegetation types on both sides and the related references. The neighboring vegetation regions were neither analysed, nor named. They have to be defined on their own merits. 


\section{Results and discussion}

The boundary line of the Pannonian vegetation region is shown in Fig. 1 (for GIS files see the Electronic Appendix).

\section{The northern boundary}

The once extensive oak steppe woodlands in the Kisalföld and the Podunajská nížina (Horváth-Godány 1977) and the loess-covered area north of them are replaced further north by Quercetum petraeae-cerridis. This community forms the boundary of the Pannonian vegetation region here. Oak forests north of this line are represented by the related, but nonPannonian Potentillo albae-Quercetum roboris (Bohn et al. 2000, Roleček 2005).

In the Váh valley and between the Biele Karpaty and Malé Karpaty, the Pannonian vegetation is represented by the subMediterranean Cotino-Quercetum pubescentis (Futák 1947, Jakucs 1961, Michalko et al. 1987, Chytrý 1994). Elsewhere, as a response to microclimatic and/or edaphic influences, continental xerothermic oak forests (Corno-Quercetum pubescentis) play the same role (Roleček 2005). These xerothermic forests do not penetrate to the north farther than the zonal Pannonian xeromesic closed oak forests. In the Ondava valley, the boundary is determined by the northern limits of Quercetum pubescenti-roboris within the Pannonian vegetation region. From the direction of the Northwestern and Northern Carpathians, the northern boundary, almost in its full length, is bordered by Carici pilosae-Carpinetum and, in exceptional cases, the related Tilio-Carpinetum (Michalko et al. 1984-86).

\section{The north-western boundary}

In the southeastern part of Moravia, the boundary of the Pannonian vegetation region again is determined mainly by the distribution limits of Quercetum pubescenti-roboris forests growing mostly on gentle loess slopes (Chytrý and Horák 1997) and alternating with meadow-steppe patches. In the Pannonian part of Moravia (cf. Kaplan 2012), a supposedly endemic community (Carici fritschii-Quercetum roboris, Chytrý and Horák 1997) has been described as a close relative of some Quercus robur-dominated open grassy oak forests in Hungary. Additional evidence of the Pannonian character is provided by the presence of large stands of Inulo hirtae-Stipetum tirsae (Dubravková et al. 2010), and the once species-rich, but now extinct or fatally degraded Thero-Salicornietea communities (Chytrý 2012). Our boundary line in Moravia approximately follows the line proposed by Chytrý (2012). The so-called Pannonian (sub-Pannonian) mesic Quercus robur-Carpinus betulus forests are widely distributed in the plains and broad valleys between hills in the warm and sub-continental parts of Slovakia, Austria, and Bohemia (Czech Republic) (Michalko et al. 1987, Mucina et al. 1993). These forests (named as Primulo veris-Quercetum roboris, Polygonato latifoliae-Carpinetum, etc.) are representatives of the forest-steppe zone and also the zone of Quercetum petraeae-cerridis. They rarely extend beyond the boundary defined by the distribution limits of Pannonian oakwoods.

The Pannonian vegetation of southeast Moravia continues to Niederösterreich, Marchfeld, the Wiener Becken, and Northern and Central Burgenland (for details, see Kilian et al. 1994, Niklfeld 1993, Willner 2013). In the lowlands and the adjacent foothills, the Pannonian vegetation with halophytic and sand steppe communities and with heavily eroded loess hillsides was richly represented in the potential vegetation (Hübl and Holzner 1975). The dominant vegetation type was Quercetum pubescenti-roboris on the lowlands, and Quercetum petraeae-cerridis (Geeerdes and Moll 1983, Karrer and Kilian 1990, Wallnöfer 2003, etc.) on the low hills. The Quercus petraea-Q. cerris belt is also rich in Pannonian communities, such as basiphilous rocky vegetation (Niklfeld 1964), xerothermic oak scrub (Ceraso-Quercetum pubescentis) and closed Quercus pubescens forest (Corno-Quercetum pubescentis) (Karrer and Kilian 1990, Wallnöfer 2003, etc.). In Niederösterreich, the boundary separates the Quercetum petraeae-cerridis on the eastern side from the Central European Carpinus betulus/Fagus sylvatica-dominated forests (e.g., Carici pilosae-Carpinetum and Primulo verisCarpinetum), and occasionally the Hercynian Potentillo albae-Quercetum roboris on the western side. The Sarmatian and Pannonian oak forests in Niederösterreich may also form transitional stands (Hübl and Holzner 1975, see also Horvát 1980, 1981, Geerdes and Moll 1983, Mucina et al. 1993).

\section{The western boundary}

South of the Leithagebirge, the boundary lies on the eastern edges of the Soproni-hegység, then turns back into Austria. In some places in Central Burgenland the vegetation is also of Pannonian character. More to southeast, the boundary line on the lower hilly areas (Répce- and Gyöngyössík, Kemeneshát) is defined by Cyclamini-Carpinetum (cf. Zólyomi 1967, 1989) on the western side. In addition to the presence of the zonal Pannonian Quercetum petraeae-cerridis forests, the eastern side of the boundary is characterized by the local occurrence of the Agrostio tenuis-Quercetum cerridis (on the Répce-sík and Kemeneshát, Csapody 1974) and the Asphodelo-Quercetum roboris (Borhidi and Járai-Komlódi 1959, Kevey 2011) communities, the latter extending from Somogy county, both occurring there for edaphic reasons. In the eastern Zala Hills, which form the western boundary, already Fagetalia communities dominate. Reaching the line of Lake Balaton (in the area of Keszthely), the border follows the riparian forests and marshes in the Zala river floodplain. In the western part of Somogy county, the boundary is drawn in the center of the transitional zone between the Illyrian Carpinion and Aremonio-Fagion forests and the Pannonian Asphodelo-Quercetum roboris extending as far south as the Drava river.

\section{The southern boundary}

The boundary is arbitrarily set as the Drava and Danube rivers in the southeastern part of Dunántúl. Along the south- 
ern boundary, the Pannonian character is most clearly represented by forests of the forest-steppe, which are typically open with numerous steppe elements, similar to the vegetation in the more northerly Vojvodina (Jovanovic 1997, Purger et al. 2014). The sand vegetation also defines the boundary. Pannonian species are richly represented in it, although the Balkan Tilia tomentosa is already co-dominant in the forests, and some southern elements also appear in the herbaceous vegetation, primarily in the well known Deliblatska Peščara (Gajić 1983). The infiltration of Balkan species in the foreststeppe forests in the more northerly Fruška Gora is already apparent (Jovanovic 1997).

More or less east of the Drina River, the boundary is defined by the partially edaphic Carpinus betulus-Quercus robur forests from the south. Elsewhere, the boundary is demarcated by the Illyrian-west-Moesian Quercus farnettoQuercus cerris forests extending from the south (Jovanovic et al. 1986). Compared to the northern and northwestern sections of the boundary, an important difference is that the Pannonian Quercetum petraeae-cerridis community is absent here.

\section{The eastern boundary}

The south-eastern boundary is formed by the plant communities of the zone of the Pannonian forest steppe. They are adjacent to Quercus farnetto, $Q$. cerris forests covering the hilly areas of foothills of the mountains bordering the Câmpia de Vest plain. North of the Mureş River, in the valley of the river up to Câmpia Transilvaniei on the western and northwestern flanks of the Munţii Apuseni, and on the hills along the Someş River the boundary is determined by the stands of Quercetum petraeae-cerridis (Pop et al. 1978, Csürös 1981, Ardelean 1999).

It has been recently recognized that the latter is one of the most extensive forest type in the Dealurile Tăşnadului, occurring zonally between 200 and 350 meters a.s.1. These forests are largely similar in species composition to those in Hungary (Karácsonyi 2010, 2011).

Thus, we drew the eastern boundary along the external margin of the cartographical representations of this forest community. This line strongly deviates from the boundary line established by phytogeographical (floristical) analyses. On the eastern side, it is bordered in the Munţii Apuseni, on the hills along the Someș River, and in the area south of the Mureş Valley by mesic deciduous forests, Quercus robur forests and communities dominated by Carpinus betulus and Fagus sylvatica, and oak forests with Quercus petraea, respectively (Ivan et al. 1993). After all, the intrusion of the Pannonian vegetation in the interior of Transylvania is best marked by the gradual disappearance of the sub-Mediterranean component, mostly Quercus cerris (Negulescu and Savulescu 1957).

In the northeast, the boundary of the Pannonian vegetation region was drawn on the arbitrary line of the Tisza and Bodrog rivers, in the middle of the broad floodplain. Here and east of this area, Pannonian vegetation types are scarce and cover only small areas, such as a narrow strip of xeromesic oak forests on the edge of mountains (Niklfeld 1974, for description see Didukh et al. 2011) and on the dry foothills rising from the plains (Fodor 1960).

In summary, the boundary of the Pannonian vegetation region runs along mostly the hills and low mountains surrounding the Great Hungarian Plain. The area of the region is $167,012 \mathrm{~km}^{2}$. Areas of considerable size with Pannonian vegetation types do not occur outside of the region boundary. We considered parts of the Északi-középhegység where Carici pilosae-Carpinetum and Melittio-Fagetum communities dominate the landscape (e.g., Börzsöny, Bükk, Mátra Mts.), and the Mecsek and Zselic Hills, as well as the Fruška Gora in the south as isolates, and thus these are not indicated in the map. The longest stretches of the boundary of the vegetation region (Northern Carpathians, Weinviertel, Transylvania) run along the external margin of Quercus cerris-Quercus petraea forests. Oak steppe forests on loess and sand, sand steppes and floodplain forests are less important in demarcating the boundary line.

The boundary of the Pannonian vegetation region is often surprisingly sharp, especially where landforms change abruptly (plain-hill country) which is often accompanied by a change in bedrock. At higher elevations, Pannonian oak woods are replaced by Carpinus/Fagus-dominated forests. The sharpness of the boundary in such cases is due to the low-light environment in the mesic oak-hornbeam forest, which is not conducive to photophilous species in the Quercetum petraeae-cerridis oak wood, but is favorable to the mountain flora. The width of the boundary may be in the order of few meters at places ("limes convergens", Dierschke 1994). Note that the floristic boundaries tend to be broader. The boundary between the Pannonicum and Alpicum in the Soproni-hegység, for instance, is a series of floristic steps within a 2-3 $\mathrm{km}$ broad zone, rather than a sharp line (Király and Szmorad 2004). Similarly, a 1-2 km wide transitional zone was detected along the boundary of Pannonicum and Hercynicum. There are several taxa in this transitional zone that are also present either in the Pannonicum or Hercynicum (Chytrý et al. 1999). In the hill country lying along the boundary between Pannonicum and Dacicum (Eastern Carpathians) (Sălaj), the transition zone is particularly broad, where gradients of Pannonian, Pontic-Pannonian and Pontic-subMediterranean species towards Câmpia Transilvaniei were observed (Karácsonyi and Negrean in litt.).

\section{Areas with transitional or uncharacteristic vegetation between vegetation regions}

The boundary line in the western section runs along an extensive transitional hilly area that is in contact with the East Alpine vegetation region in the west. This transitional character is shaped by influences from the two neighboring regions, and also those of the West-Balkan, the latter of which manifesting themselves in the species composition of the extensive Carpinus-Quercus and Fagus forests (Pócs 1960). An additional feature of the area is the presence of patches of mixed forest with Pinus sylvestris (Genisto nervatae-Pinetum 
sylvestris) with associated vegetation complexes, which are regarded as the extant representatives of the once continuous southern boreal European forest zone, relics of the early stages of postglalcial forest development (Pócs et al. 1958, Pócs 1960), which were not replaced later by broadleaved forests. It is this peculiar mix of vegetation types and the transitional character that render this large area confined between two vegetation regions a certain degree of uniqueness. Therefore, we regard it as being significantly different from either of the two neighboring (East Alpine and Pannonian) vegetation regions.

That the transitional zones between vegetation-based ecoregions may be rather broad is advocated by Bailey (2005) with examples (see also Küchler 1973). The existence of transitional and character-poor areas is also recognized in geographical landscapes where transitions regularly develop as well (Kádár 1965, for overlapping and noncomplementary landscapes, see Kádár 1941).

More generally, the boundaries of biogeographical regions are represented by sharp lines at certain sections and broad transitional zones elsewhere (Oliviero et al. 2013).

There is another problem in the area south of the transitional zone. In Slovenia, Wraber (1969) circumscribed a subPannonian area, but he did not demonstrate the occurrence of Pannonian communities within it. Fukarek $(1977,1979)$, who studied the boundaries of the entire Illyrian floristic province, went even further than Wraber and declared the area between the Sava river and the northeastern flanks of the Dinaric Alps where he proposed the boundary, and also the area on the left bank of the river, as parts of the Pannonicum floristic province. Marinček (1995) placed the boundary of the Illyrian floristic province farther north, but he also considered the area north of the Sava river as part of the Pannonian floristic region. He did not support his view with evidence of Pannonian communities occurring in the long Croatian part of the area between the Drava and Sava rivers. It is clear that the aforementioned researchers relativized the Pannonian character, and did not adopt the principle that every region has to be evaluated according to its own criteria. Unfortunately, they applied both floristic and vegetation geographical arguments when establishing boundaries, which makes the repeatability of the delimitation methodology more difficult.

We argue that botanists have to accept the notion that there exist uncharacteristic areas, which are difficult or even impossible to assign to any phytogeographical region. Such an area is found between the Drava and Sava rivers, which is, in our opinion, not a part of the Pannonian vegetation region.

\section{Coincidence of the floristic and vegetation region boundaries}

We found that the boundaries of the Pannonicum floristic province and the Pannonian vegetation region did not fully coincide. The degree of deviation varies greatly. In cases when there is a rather uniform environmental gradient that is not disrupted by other environmental factors, this deviation tends to be small. This is the case in the north, where the boundary of the Pannonian flora province towards the Carpathians has been long studied (e.g., Moesz 1911, and with more species: Futák 1966). The line proposed by Futák (1966) is in good agreement with the boundary of the Pannonian vegetation region (which we determined by using mainly the map of Michalko et al. 1984-1986). The close correspondence (exceptions being only the Slovenský Kras) may be the consequence of the rather uniform altitudinal gradient to the Carpathians, which renders the boundary between the Quercetum petraeae-cerridis and Carpinus betulus-dominated forests relatively unequivocal.

In other cases, however, the discrepancy between the boundary lines of the Pannonic floristic province and the Pannonian vegetation region seems to be larger. In Western Hungary, the distance between the two lines may reach 10$60 \mathrm{~km}$ (Fig. 1.) This area is covered by the floristic sector of Western Dunántúl (Gáyer 1925, Jávorka 1924-25, Soó 1933, Kárpáti 1958, 1960; see the maps in Pócs 1981). The vegetation of the area has been characterized above. It essentially lacks climatically zonal Pannonian communities with the exceptions of some fragments (mostly extrazonal Quercetum petraeae-cerridis stands (Szmorad 1994, Király et al. 1999), and some xerothermic vegetation at the western border (Kőszeg) of the area (Gáyer 1925). Pannonian endemisms are rare here $\left(0-1\right.$ species $/ \mathrm{cca} .140 \mathrm{~km}^{2}$ mapping-grid units as opposed to 3-10(15) species/grid units in the middle of the basin (Bartha et al. 2015). Meusel et al. (1965) do not regard this area as part of the Pannonicum floristic province. Based on the analysis of the patterns of the Central European flora they define a region called Praenorico-Slowenian floristic subprovince, covering West- and South-West Hungary, Burgenland, South Styria and northern Slovenia. This subprovince is separated from the great provinces of Alpicum, Illyricum and Pannonicum. The subprovince has an intermediate, transitional flora. Its Eastern border is very close to the corresponding borderline of the Pannonian vegetation region. The exact method of delimitation was not published. We suggest to re-think the Western border of the Pannonicum floristic region based on the distribution of Pannonian, continental, pontic, pontic-submediterranean and xerophilous submediterranean taxa. Our expectation is that a new, alternative floristic border could be drawn closer to our vegetation region border than the floristic border delimited by Soó (1947) and Pócs (1981) (Fig. 1). Large disagreements between boundary lines exist in the east as well. In our opinion, the boundaries of the Pannonicum floristic province should be revised in the near future based on statistical analyses using modern, integrated floristic databases.

\section{Conclusions}

Methodologically, the application of high resolution maps - especially those with a scale of 1:500,000 and even of 1:200,000 - significantly modified the preliminary boundaries drawn up on the 1: 25,000,000 base map. Meticulous evaluation of the large number of vegetation descriptions, texts and data tables, helped us assess patches along the boundaries, and often led to the correction of the base map. Without this 
process, the eastern boundary of the region could not have been drawn up at all.

Our method is simple, open to improvements, and the results can be validated and falsified. The small number of relevant vegetation units (in the order of ten) greatly simplifies the method compared to regionalization on a floristical basis. In this case, the regional distribution of many more units should be considered including the Eurasian (mainly SouthEurasian), continental, Pontic, Pontic-Pannonian floristic elements, Pannonian endemics, and a substantial portion of species with sub-Mediterranean distribution range (several hundred taxa, see Pócs 1981).

No doubt that maps with boundaries of phytogeographical units determined by the geographical ranges of taxa, and their gradient-like interpretations may provide answers to a number of more sophisticated questions. However, floristic data bases that are necessary to determine the boundaries are still unavailable along the eastern and southern borders.

Comparisons of boundaries of vegetation and floristic regions are rarely done. We argue that vegetation region boundaries can assist us to reevaluate long-established floristic region boundaries. We showed, however, that in some cases neighboring regions are not in direct contact: there exist uncharacteristic areas, which are difficult or even impossible to assign to any phytogeographical region.

Our map provides an opportunity to the European Union to use a scientifically more sound biogeographical circumscription of the Pannonian region in her Natura 2000 and other programs.

Acknowledgements. We thank A. Čarni, M. Chytrý, K. Karácsonyi, G. Negrean, H. Niklfeld, T. Pócs, D. Purger, and $\mathrm{W}$. Willner for their help in the delineation process and in finding relevant new literature sources, S. Bartha for helpful comments on an earlier version of the manuscript, Z. Barina, B. Kevey, F. Szmorad, and Z. Varga for fruitful discussions on the topic in the last years and G. Lendvai for language revision. G. Király was supported by the project "Agrárklíma.2 VKSZ-12-1-2013-0034”.

\section{References}

Anon. 2014. European Commission, Environment 2000: Natura 2000 - Pannonian biogeographical region. - URL: http://ec.europa.eu/ environment/nature/natura2000/sites_hab/biogeog_regions/index_en.htm\#pannonian [accessed 15 Sept 2014].

Ardelean, A. 1999. Flora şi vegetaţia din valea Crişului Alb [Flora and vegetation in the Crişul Alb river valley]. Vasile Goldiş University Press, Arad.

Bailey, R. G. 2005. Identifying ecoregion boundaries. Environ. Manag., Suppl. 34: 14-26.

Bartha, D., G. Király, D. Schmidt, V. Tiborcz, Z. Barina, J. Csiky, G. Jakab, B. Lesku, A. Schmotzer, R. Vidéki, A. Vojtkó and Sz. Zólyomi (eds), 2015. Magyarország edényes növényfajainak elterjedési atlasza. [Distribution Maps of the Vascular Flora in Hungary] Nyugat-magyarországi Egyetem Kiadó, Sopron.
Bohn, U., G. Gollub and C. Hettwer (eds), 2000. Karte der natürlichen Vegetation Europas, 1:2500 000. Bundesamt für Naturschutz, Bonn - Bad Godesberg.

Bölöni, J., Zs. Molnár and A. Kun (eds), 2011. Magyarország élöhelyei. A hazai vegetációtípusok leirása és határozója [Habitats of Hungary. Description and Identification of Vegetation Units]. MTA Ökológiai és Botanikai Kutatóintézete, Vácrátót.

Bölöni, J., Zs. Molnár, M. Biró and F. Horváth 2008. Distribution of the (semi-)natural habitats in Hungary II. Woodlands and shrublands. Acta Bot. Hung. 50 (Suppl.): 107-148.

Borbás, V. 1905. Magyarország természetes flórájának tagozódása [Classification of the Natural Flora of Hungary]. In: György, E. (ed.), A Föld és népei V. Franklin Társulat, Budapest. pp. 99-127.

Borhidi, A. and M. Járai-Komlódi. 1959. Die Vegetation des Naturschutzgebietes des Baláta-Sees. Acta Bot. Hung. 5: 259320 .

Borhidi, A., B. Kevey and G. Lendvai. 2012. Plant Communities of Hungary. Akadémiai Kiadó, Budapest.

Chytrý, M. 1994. Xerothermic oak forests in the middle Váh basin and in the southern part of the Strážovská hornatina Upland, Slovakia. Scr. Fac. Sci. Natur. Univ. Masaryk Brun. Biol. 2223(1992-93): 121-134.

Chytrý, M. 2012. Vegetation of the Czech Republic: diversity, ecology, history and dynamics. Preslia 84: 427-504.

Chytrý, M. and J. Horák. 1997. Plant communities of the thermophilous oak forests in Moravia. Preslia 68: 193-204.

Chytrý, M., V. Grulich, L. Tichý and M. Kouril. 1999. Phytogeographical boundary between the Pannonicum and Hercynicum: a multivariate landscape analysis in the Podyji/ Thayatal National Park, Czech Republic/Austria. Preslia 71: 23-41.

Csapody, I. 1974. Die Agrostio-Quercetum roboris-cerris Wälder der Kleinen Ungarischen Tiefebene. Acta Bot. Hung. 20: 23-30.

Csűrös, I. 1981. A Nyugati-Szigethegység élövilágáról [On the biota of the Munţii Apuseni, Transylvania]. Tudományos és Enciklopédiai Kiadó, Bukarest.

Didukh, Y.P., T.V. Fitsailo, I.A. Korotchenko, D.M. Iakushenko and N.A. Pashkevych. 2011. Biotopi lisovö̈ ta lisostepovoï zon Ukraïni [Biotopes in the forest and forest-steppe zones in Ukraine]. LLC MACROS, Kyiv.

Dierschke, H. 1994. Pflanzensoziologie. Grundlagen und Methoden. Eugen Ulmer, Stuttgart.

Dubravková, D., M. Chytrý, W. Willner, E. Illyés, M. Janišová and J. Kállayné-Szerényi. 2010. Dry grasslands in the Western Carpathians and the northern Pannonian Basin: a numerical classification. Preslia 82: 165-221

Fekete, G., Zs. Molnár, E. Magyari, I. Somodi and Z. Varga. 2014 A new framework for understanding Pannonian vegetation pattern: regularities, deviations and uniqueness. Community Ecol. 15: $12-26$

Fekete, L. and T. Blattny. 1913. Az erdészeti jelentöségü fák és cserjék elterjedése a Magyar Állam területén [Distribution of forest trees and shrubs in the territory of the Hungarian State]. Joerges, Selmecbánya.

Fodor, I. 1960. Az Északkeleti Kárpátok déli vulkanikus előhegyeinek növénytakarója [Plant cover of the southern volcanic foothills of the Northeastern Carpathians]. Bot. Közl. 48: 281-283.

Fukarek, P. 1977. Die Gliederung der illyrischen Florenprovinz in natürliche Vegetationsgebiete mit Hilfe der Waldgesellschaften. Centralblatt f. d. Gesamte Forstwesen 94: 154-162. 
Fukarek, P. 1979. Die Pflanzengeographische Abgrenzung des illyrischen vom moesischen Gebiet. Phytocoenologia 6: 434-445.

Fukarek, P. and B. Jovanović (eds), 1986. Karta Prirodne Potencijalne Vegetacije SFR Jugoslavije, 1: 1000000 [Natural potential vegetation of the SFR Jugoslavia, 1: 1000 000]. In: Jovanović, B., R. Jovanović and M. Zupančič (eds), Prirodna Potencijalna Vegetacija Jugoslavije. Ljubljana.

Futák, J. 1947. Xerothermná vegetácia skupiny Kňažného Stola (západné Slovensko) [Xerothermic vegetation in the Kňažný Stol district, Western Slovakia]. Spolok sv. Vojtecha, Trnava.

Futák, J. 1966. Fytogeografické členenie Slovenska [Plant geographical partition of Slovakia]. In: Futák, J. (ed.), Flóra Slovenska I., SAV, Bratislava. pp. 535-538.

Gajić, M. (ed.), 1983. Flora Deliblatske Peščare [The flora of the Deliblato sands]. Institut za biologiju, Novi Sad.

Gáyer, Gy. 1925. Vasvármegye fejlődéstörténeti növényföldrajza és a praenorikumi flórasáv [The phylogenetical plant geography of Vas County and the floristic belt of the Praenoricum]. Vasvármegye és Szombathely Város Kultúregyesülete és a Vasvármegyei Múzeum Évkönyve 1: 1-43.

Geerdes, B. and G. Moll. 1983. Waldgesellschaften der Hainburger Berge und angrenzender Gebiete (Niederösterreich). Verh. Zool.Bot. Ges. Österreich 121: 5-37.

González-Orozco, C.E., M.C. Ebach, S. Laffan, A.H. Hornhill, N.J. Knerr, A.M. Clements, N.S. Nagalingum, B.D. Mischler and J.T. Miller. 2014. Quantifying phytogeographical regions of Australia using geospatial turnover in species composition. PloS One 9(3): e92558.

Hegg, O., C. Béguin and H. Zoller. 1993. Atlas schutzwürdiger Vegetationstypen der Schweiz. Bundesamt für Wald, Umwelt und Landschaft, Bern.

Horvát, A.O. 1980. Potentillo-Quercetum (sensu latissimo) Wälder II. Janus Pannonius Múz. Évk. 24: 11-32.

Horvát, A.O. 1981. Potentillo-Quercetum (sensu latissimo) Wälder III. Janus Pannonius Múz. Évk. 25: 31-70.

Horváth-Godány, J. 1977. Vegetációrekonstrukció DélnyugatSzlovákia löszvidékén [Vegetation reconstruction on the loessregion of Western Slowakia]. PhD Thesis, MTA ÖBKI, Vácrátót.

Hübl, E. and W. Holzner. 1975. Grundzüge der Vegetationsgliederung Niederösterreichs. Phytocoenologia 2: 312-328.

Ivan, D., N. Doniţă, G. Coldea, V. Sanda, A. Popescu, T. Chifu, N. Boscaiu, D. Mititelu and M. Paucă-Comanescu. 1993. Vegetation potentielle de la Roumanie. Braun-Blanquetia 9: 3-79.

Jakucs, P. 1961. Die phytozönologischen Verhältnisse der Flaumeichen-Buschwälder Südostmitteleuropas. Akadémiai Kiadó, Budapest.

Jávorka, S. 1924-1925. Magyar Flóra [Hungarian Flora]. Studium, Budapest.

Jeanplong, J. 1956. Flóraelemek szerepe a flórahatárok megvonásában Északnyugat-Dunántúlon [The role of floristic elements in laying out the floristic boundaries of Northwestern Transdanubia]. Bot. Közl. 46: 261-266.

Jovanović, B. 1997. The order of downy oak forests Quercetalia pubescentis Br.-B1. (1931) 1932. In: Sarić, M. and O. Vasić (eds), The Vegetation Vegetation of Serbia. Forest Communities Communities I. Serbian Academy of Sciences and Arts, Department of Natural and Mathematical Sciences, Beograd. pp. 2-106.

Jovanović, B., R. Jovanović and M. Zupančič (eds), 1986. Prirodna potencijalna vegetacija Jugoslavije [The natural potential vegetation of Yugoslavia]. Naučno veće Vegetacijske karte Jugoslavije, Ljubljana.
Kádár, L. 1941. A magyar nép tájszemlélete és Magyarország tájnev$e i$ [Attitude of the Hungarian people towards the landscape and the landscape names in Hungary]. Országos Táj- és Népkutató Intézet, Budapest.

Kádár, L. 1965. Biogeográfia [Biogeography]. Tankönyvkiadó, Budapest.

Kaplan, Z. 2012. Flora and phytogeography of the Czech Republic. Preslia 84: 505-573.

Karácsonyi, K. 2010. Cseres-tölgyes és mészkerülő tölgyes erdők a Tasnádi-dombvidéken (Erdély, Románia) [Turkey oaksessile oak and acidophilic oak forests on the Dealuri Tăşnad, Transylvania]. Kanitzia 17: 151-178.

Karácsonyi, K. 2011. Flora şi vegetatia dealurilor Tăşnadului şi a colinelor marginale [Flora and vegetation of Dealurile Tăşnadului and its environs]. "Vasile Goldis" University Press, Arad.

Kárpáti, Z. 1958. Über die westungarisch-burgenländischen Florengrenze. Bot. Közlem. 47: 313-321.

Kárpáti, Z. 1960. Die pflanzengeographische Gliederung Transdanubiens. Acta Bot. Hung. 6: 45-53.

Karrer, G. and W. Kilian. 1990. Standorte und Waldgesellschaften im Leithagebirge, Revier Sommerein. Mitteilungen der Forstlichen Bundesversuchsanstalt Wien 165, Wien.

Kerner, A. and R. Wettstein. 1888. Florenkarte von ÖsterreichUngarn. Hölzel, Wien.

Kevey, B. 2008. Magyarország erdőtársulásai [Forest communities of Hungary]. Tilia 14: 1-488.

Kevey, B. 2011. A Bakonyalja homokvidékének erdei III. Homoki cseres-tölgyesek (Asphodelo-Quercetum roboris [Borhidi et Járai-Komlódi 1959] Borhidi in Borhidi - Kevey 1996) [Forests at Bakonyalja III. Turkey oak forests on sand]. Folia Mus. Hist.Nat. Bakonyiensis 28: 9-37.

Kilian, W., F. Müller und F. Starlinger 1994. Die forstlichen Wuchsgebiete Österreichs. Eine Naturraumgliederung nach waldökologischen Gesichtspunkten. Forstliche Bundesversuchsanstalt, Waldforschungszentrum, Wien.

Király, A. and G. Király 2008. Vegetationsmuster von Waldpflanzen am Südwestrand der Kleinen Ungarischen Tiefebene. Neilreichia 5: 19-109.

Király, G. (ed.), 2009. Új magyar füvészkönyv. Magyarország hajtásos növényei. Határozókulcsok [New Hungarian Herbal. The vascular plants of Hungary. Identification key]. Aggteleki Nemzeti Park Igazgatóság, Jósvafő.

Király, G. and F. Szmorad. 2004. A Soproni-hegység növényföldrajzi viszonyai [Plant geography of the Sopron Mts]. Flora Pannonica 2(2): 22-36.

Király, G., A. Kun and F. Szmorad. 1999. A Vas-hegy csoport vegetációja és florisztikai érdekességei [The vegetation and floristic pecularities of the Vas-hegy group]. Kitaibelia 4: 119-142.

Király, G., Zs. Molnár, J. Bölöni, J. Csiky and A. Vojtkó (eds), 2008. Magyarország földrajzi kistájainak növényzete [The vegetation of physical geographical microregions of Hungary]. MTA Ökológiai és Botanikai Kutatóintézete, Vácrátót.

Kovács, M. 1975. Beziehung zwischen Vegetation und Boden (Die Bodenverhältnisse der Waldgesellschaften des Mátragebirges). Budapest, Akadémiai Kiadó.

Kovács, M. and J. Podani. 1979. Zönologische Untersuchung der Traubeneichen-Zerreichenwälder der Tarna-Gegend (Nordungarisches Mittelgebirge). Phytocoenologia 6: 439-454.

Küchler, A.W. 1973. Problems in classifying and mapping vegetation for ecological regionalization. Ecology 54: 512-523. 
Küchler, W. 1985. Potential natural vegetation, 1: 7,500,000 scale. In: National Atlas of the United States. Department of the Interior, US Geological Survey, Reston, Virginia.

Marinček, L. 1995. Contribution to demarcation and phytogeographic division of the Illyrian floral province, based on vegetation and flora. Gortania 16: 99-124.

Meusel, H. and E. Jäger (eds), 1992 Vergleichende Chorologie der zentraleuropäischen Flora III. Gustav Fischer, Jena, Stuttgart, New York.

Meusel, H., E. Jäger and E. Weinert. 1965. Vergleichende Chorologie der zentraleuropäischen Flora I. Gustav Fischer, Jena, Stuttgart, New York.

Michalko, J., D. Magic, J. Berta, K. Rybníček and E. Rybníčková 1987. Geobotanical map of CSSR. Slovak Socialist Republic. VEDA, Bratislava.

Michalko, J., J. Berta, D. Magic and Š. Maglocký, 1979. Potenciálna prirodzená vegetácia, 1: 500000 [Potential natural vegetation, 1: 500 000]. SAV, Bratislava.

Michalko. J., D. Magic, J. Berta, Š. Maglocký and A. Spániková. 1984-1986. Geobotanical map of CSSR, Slovak Socialist Republic Maps. VEDA, Bratislava.

Mikyška, R., M. Deyl, J. Holub, M. Husová, J. Moravec, R. Neuhäusl and Z. Neuhäuslová-Novotná. 1968-1972. Geobotanická mapa CSSR 1. Ceské Zemé [Geobotanical map of the CSSR I. Czech lands]. Akademia, Praha.

Moesz, G. 1911. Adatok Bars vármegye flórájához [Data to the flora of Bars County]. Bot. Közl. 10: 171-185.

Molnár, Cs., Zs. Molnár, Z. Barina, N. Bauer, M. Biró, L. Bodonczi, A.I. Csathó, J. Csiky, J.Á. Deák, G. Fekete, K. Harmos, A. Horváth, I. Isépy, M. Juhász, J. Kállayné Szerényi, G. Király, G. Magos, A. Máté, A. Mesterházy, A. Molnár, J. Nagy, M. Óvári, D. Purger, D. Schmidt, G. Sramkó, V. Szénási, F. Szmorad, Gy. Szollát, T. Tóth, T. Vidra and V. Virók. 2008a. Vegetation-based landscape regions of Hungary. Acta Bot. Hung. 50 (Suppl.): 4758.

Molnár, Zs., M. Biró, J. Bölöni and F. Horváth. 2008b. Distribution of the (semi-)natural habitats in Hungary I. Marshes and grasslands. Acta Bot. Hung. 50 (Suppl.): 59-105.

Molnár, Zs., S. Bartha, E. Illyés, G. Tímár, F. Horváth, A. Révész, A. Kun, Z. Botta-Dukát, J. Bölöni, M. Biró, L. Bodonczi, J.Á. Deák, P. Fogarasi, A. Horváth, I. Isépy, L. Karas, F. Kecskés, Cs. Molnár, A. Ortmanné Ajkai and Sz. Rév. 2007. A grid-based, satellite-image supported, multi-attributed vegetation mapping method (MÉTA). Folia Geobot. 42: 225-247.

Mucina, L., G. Grabherr and S. Wallnöfer. 1993. Die Pflanzengesellschaften Österreichs III. Wälder und Gebüsche. Gustav Fischer Verlag, Jena, Stuttgart, New York

Negulescu, E. and A. Săvulescu 1957. Dendrologie. Edit. AgroSilvică de Stat, București.

Niklfeld, H. 1964. Zur xerothermen Vegetation im Osten Niederösterreichs. Verh. Zool.-Bot. Ges. Wien 103-104: 152-181.

Niklfeld, H. 1974. Natürliche Vegetation. In: Breu, J. (ed.), Atlas der Donauländer, Deuticke, Wien.

Niklfeld, H. 1993. Pflanzengeographische Charakteristik Österreichs. In: Mucina, L., G. Grabherr and S. Wallnöfer (eds.), Die Pflanzengesellschaften Österreichs I. Gustav Fischer Verlag, Jena, Stuttgart, New York. pp. 43-75.

Oliviero, J., A.L. Márquez and R. Real. 2013. Integrating fuzzy logic and statistics to improve the reliable delimitation of biogeographic regions and transition zones. Syst. Biol. 62: 1-21.

Pócs, T. 1960. Die zonalen Waldgesellschaften Südwestungarns. Acta Bot. Hung. 6: 75-105.
Pócs, T. 1981. Magyarország növényföldrajzi beosztása [Plant geographical division of Hungary]. In: Hortobágyi, T. and T. Simon (eds), Növényföldrajz, társulástan és ökológia. Nemzeti Tankönyvkiadó, Budapest. pp. 120-155.

Pócs, T., É. Domokos-Nagy, I. Pócs-Gelencsér and G. Vida. 1958. Vegetationsstudien im Örség. Akadémiai Kiadó, Budapest.

Pop, I., A. Ardelean, V. Codoreanu, A. Crișan, M. Csűrös-Káptalan, S. Csűrös, E. Ghişa, I. Hodişan, O. Ratiu and E. Szász. 1978. Flora și vegetaţia Munţilor Zarand [Flora and vegetation of the Zarand Mts]. Contrib. Bot. 18: 1-215.

Purger, D., A. Lengyel, B. Kevey, G. Lendvai, A. Horváth, Z. Tomić and J. Csiky. 2014. Numerical classification of oak forests on loess in Hungary, Croatia and Serbia. Preslia 86: 47-66.

Rapaics, R. 1910. Magyarország növényföldrajzi tagozódása [Phytogeographical partition of Hungary]. Pótfüzetek a Természettudományi Közlönyhöz 97: 34-41.

Roleček, J. 2005. Vegetation types of dry-mesic oak forests in Slovakia. Preslia 77: 241-261.

Schmithüsen, J. 1968. Allgemeine Vegetationsgeographie. 3. Auflage. Berlin. De Gruyter.

Schubert, R. 1991. Lehrbuch der Ökologie. 3. Auflage. Fischer, Jena

Soó, R. 1932. Florenkarte Europas. Pflanzenareale III. Heft 7, Karte 1.

Soó, R. 1933. Floren- und Vegetationskarte des historischen Ungarns. A Debreceni Tisza István Tudományos Társaság Honismertetó Bizottságának Kiadványai 8: 5-35.

Soó, R. 1945. Növényföldrajz. Magyar Természettudományi Társulat, Budapest.

Soó R. 1947: Flora Carpato-Pannonica. Acta Geobotanica Hungarica 6: $114-117$

Soó, R. 1963. Systematische Übersicht der pannonischen Pflanzengesellschaften VI. Die Gebirgswälder II. Acta Bot. Hung. 9: 123150.

Soó, R. 1965. Növényföldrajz [Plant geography]. Tankönyvkiadó, Budapest.

Szmorad, F. 1994. A Kőszegi-hegység erdőtársulásai [Forest communities of the Köszeg Mts]. In: Bartha, D. (ed.), A Köszegihegység vegetációja. Erdészeti és Faipari Egyetem, Sopron. pp. 106-132.

Tallós, P. 1959. Erdő- és réttípusok a Széki-erdőben [Forest and meadow types in the Széki-erdö]. Erdészeti Kutatások 6: 301353.

Wallnöfer, S. 2003. Thermophile Eichenwaldgesellschaften im Osten Österreichs. Verh. Zool.-Bot. Ges. Österreich 140: 1-16.

Walter, H. and H. Straka. 1970. Arealkunde - Floritisch-historische Geobotanik. Ulmer, Stuttgart.

Willner, W. 2013. Pannonische Steppenrasen in Österreich. In Baumbach, H. and S. Pfützenreuter (eds), Steppenlebensräume Europas. Gefährdung, Erhaltungsmassnahmen und Schutz. Thüringer Ministerium für Landwirtschaft, Forsten, Umwelt und Naturschutz, Erfurt, pp. 151-162.

Wraber, M. 1969. Pflanzengeographische Stellung und Gliederung Sloweniens. Vegetatio 17: 176-199.

Zhang, X. (ed.), 2007. Vegetation Map of the People's Republic of China, 1: 1 1,000 000,000. The Geological Publishing House, Beijing.

Zólyomi, B. 1941. Adatok a Kisalföld növényföldrajzának ismeretéhez [Data to the knowledge of the plant geography of the Kisalföld]. Bot. Közl. 38: 95-96.

Zólyomi, B. 1967. Rekonstruált növénytakaró, 1: 1,5 millió [Reconstructed vegetation, 1:1,5 million]. In: Radó, S. (ed.) Magyarország Nemzeti Atlasza. Kartográfiai Vállalat, Budapest. 
Zólyomi, B. 1989. Természetes növénytakaró, 1: 1500000 [Natural vegetation, 1: 1,5 million]. In: Pécsi, M. (ed.), Magyarország Nemzeti Atlasza. Kartográfiai Vállalat, Budapest. p. 89.

Received December 15, 2015 Revised April 15, 2016 Accepted May 15, 2016

\section{Electronic Appendix}

GIS file of the boundary line of the Pannonian vegetation region. The file may be downloaded from www.akademiai. com. 